\title{
FEELINGS OF MOTHERS OF INFANTS WITH MICROCEPHALY: A QUALITATIVE STUDY
}

\author{
SENTIMENTOS DE MÃES DE LACTENTES COM MICROCEFALIA: UM \\ ESTUDO QUALITATIVO
}

\section{Cláudia Maria Sousa de CARVALHO ${ }^{1}$; Antônio Adeilson Mendes PEREIRA ${ }^{2}$; Geany Ferreira de ABREU ${ }^{2}$; Lourena Joyce Matos PAZ ${ }^{2}$; Lydia de Carvalho PIRES ${ }^{3}$; Camila Aparecida Pinheiro Landim ALMEIDA ${ }^{4}$; Fernanda Cláudia Miranda AMORIM ${ }^{5}$; Magda Coeli Vitorino Sales COÊLHO' ${ }^{6}$; Adélia Dalva da Silva OLIVEIRA ${ }^{7}$; Ana Raquel Batista de CARVALHO ${ }^{2}$; Guilherme Guarino de Moura SÁ ${ }^{8}$}

1. Master in Public Policy, Federal University of Piaui. Professor of the Undergraduate Nursing course at UNINOVAFAPI University Center; 2. Nurse, UNINOVAFAPI University Center; 3. Psychologist, Mental Health Specialist, UNINOVAFAPI University Center; 4. $\mathrm{PhD}$ in Sciences. Professor at the Professional Master Program in Family Health at UNINOVAFAPI University Center; 5. PhD student in Biomedical Engineering, Professor of the Undergraduate Nursing course at UNINOVAFAPI University Center; 6. Master student in Family Health, Professor of the Undergraduate Nursing course at UNINOVAFAPI University Center; 7. PhD in Public Policy, Coordinator of the Undergraduate Nursing course at UNINOVAFAPI University Center; 8. PhD student in Nursing, Professor of the Technical Nursing Course at the Technical College of Bom Jesus, Federal University of Piauí. camila@ uninovafapi.edu.br

\begin{abstract}
Microcephaly is a congenital malformation in which the brain does not develop properly. It can be the result of a series of factors, from malnutrition of the mother, drug abuse, infections during pregnancy, among others. In the family context, the birth of a child with microcephaly, produces profound changes and needs in the psychosocial and financial dimensions of the family. Based on this, the objective was to unveil the feelings experienced by mothers of infants with microcephaly. For that, a descriptive, exploratory study was developed with a qualitative data approach, carried out in a reference maternity hospital, located in a great city of Northeastern Brazil, with 20 (twenty) mothers. In order to process the collected data, the IRaMuTeQ software was used and the results were analyzed by the Hierarchical Descending Classification. Six classes were found: Feelings before the diagnosis of microcephaly; Feelings in coping with microcephaly; Acceptance of the diagnosis of microcephaly and the importance of family support; Feelings related to the limitations and the search of care for infants with microcephaly; Feelings related to the routine of mothers of infants with microcephaly and Feeling related to the mother's reaction to the prejudice of society. It has been shown that for mothers, the birth of a child with microcephaly is a delicate and conflicting moment in their lives, because it is a new and unexpected event in their life, also because it is the loss of the idealized baby, to be replaced by a baby who will need more specific care.
\end{abstract}

KEYWORDS: Microcephaly. Emotions. Congenital Abnormalities. Nursing Care.

\section{INTRODUCTION}

Microcephaly is a congenital malformation in which the brain does not develop properly. Having a cephalic perimeter lower than expected for age and sex and, depending on its etiology, may be associated with structural malformations of the brain or secondary to various causes (BRASIL, 2015a).

In the pediatric care, cephalic perimeter measurement is a fundamental clinical data, since it is the basis for the diagnosis of various neurological diseases. For this reason, health professionals should be aware of the most frequent causes of microcephaly, as well as the normality patterns of the skull growth (BRASIL, 2015a).

Microcephaly can be classified into: congenital microcephaly, which is present at birth, and postnatal microcephaly which refers to a failure of normal growth of the cephalic perimeter after birth. Generally, in most cases of microcephaly, children are delayed in neuropsychomotor development and, in some cases, also compromise the sensory functions (hearing and vision) (BRASIL, 2015b).

Some factors may predispose to the development of microcephaly, such as maternal malnutrition, drug abuse and infections during the gestation, such as rubella, toxoplasmosis and cytomegalovirus, among others. A variety of metabolic and/or genetic abnormalities and syndromes, as well as unknown causes can affect development of the brain and associate with the disease (REIS, 2015).

In the family context, the birth of a child with microcephaly produces profound changes and needs in the psychosocial and financial dimensions of the family, and especially of the mother, for being the main caretaker of the child. However, even when aware of responsibilities and dedicated to the care of the child, mothers of babies with 
microcephaly experience varying feelings such as: guilt, frustration, sadness, fear, doubt and insecurity in the face of the difficult reality of the birth of a child with disabilities (SILVA; MARANHÃO, 2012).

Becoming a mother provokes in the woman the obligation to have a child within a "pattern" idealized by society. Gestation, childbirth, and birth can be considered rewards in which the woman has confirmation of her vitality and the task of procreating. However, the birth of a child with microcephaly may break with this paradigm, which may lead to limitations in the routine of life and autonomy, also allowing the emergence of ambiguous feelings towards the child (SILVA; VASCONCELOS; ARAÚJO, 2017).

Therefore, revealing the diagnosis of microcephaly of the expected child can be a very traumatic time for the family and, especially, for the mother. Thus, the news of the diagnosis of microcephaly of the newborn can trigger suffering and rejection by the mother (SILVA; MARANHÃO, 2012)

Therefore, considering that the feelings define the attitudes and the way of relating of the human being, knowing the feelings of mothers of babies with microcephaly can contribute to the planning of a set of care strategies to the binomial: mother-child, providing acceptance, protection and care of the mother in relation to the new being and in relation to herself. Thus, the objective was to unveil the feelings experienced by mothers of infants with microcephaly.

\section{MATERIAL AND METHODS}

This was a descriptive, exploratory study with a qualitative approach to the data. The study was carried out in a reference maternity hospital, located in a great city of northern Northeastern Brazil (MINAYO, 2010).

The research site counts with the State Microcephaly Reference Center organized to treat newborns with suspected microcephaly who are offered consultations and evaluation with pediatricians, neuropediatricians, neurosurgeons, neonatologists, ophthalmologists, physiotherapists and obstetricians. As well as complementary exams, such as auditory and eye fundus screening (RIBEIRO et al, 2018).

The study participants were mothers in the stage of infants diagnosed with microcephaly. According to information gathered in the health service scenario of the study, currently, approximately 45 (forty-five) mothers of infants with microcephaly are followed. The recruitment of participants was interrupted after reaching the depth of the meanings expressed in the technique of data collection, given the recurrence and homogeneity of the information collected, after meeting the study objective and responding to the researchers' concerns (MINAYO, 2017). Thus, the number of participants was set in 20 (twenty) mothers of infants with microcephaly.

The inclusion criteria in the study were: mothers of infants diagnosed with microcephaly, over 18 years of age and who were being followed up at the reference maternity hospital.

Regarding the exclusion criteria, the following were considered: mothers of infants with microcephaly, whose child was not followed up at the reference maternity hospital; also, mothers of infants with microcephaly under 18 years.

Data collection was performed in November and December 2016. For this purpose, a technique defined as semi-structured interview was used, which was performed in a reserved room, using a tape recorder and an interview script. The script contained closed questions to outline the sociodemographic profile of the participants and the open question: "Tell me about your feelings when you receive news of your child's microcephaly diagnosis."

The privacy and identity of the participants were respected, which received increasing numbers, a factor that will guarantee the confidentiality of their participation. The time of the semi-structured interview was free, but did not exceed the average of thirty (30) minutes with each participant.

For the analysis of the data collected, the software IRaMuTeQ (Interface of MultiDimensional Analyzes of Texts set of Questionnaires) was used, later analyzed by the Descending Hierarchical Classification (DHC) (RODRIGUES et al, 2017; JESUS et al, 2017; SOUSA et al, 2016; RATINAUD; MARCHAND, 2012). The use of statistical software has helped to apprehend the object of research in the qualitative approach, and the IRaMuTeQ stands out for the actuality and ease being reported in several researches in the health area (RODRIGUES et al, 2017; JESUS et al, 2017; SOUSA et al, 2016; SOUSA et al, 2015).

For this research the value of $p$ ( $p$-value) of 0.05 was adopted. Thus, for every $p \leq 0.05$, the test is considered significant, and the word belongs to the class stipulated in the software (RODRIGUES et al, 2017; JESUS et al, 2017). The study obeyed all the criteria that govern human research. The ethical 
Feelings of mothers...

aspects of confidentiality and codification of the participants were respected. The letter "P" was added, which represented "participant", followed by a sequential Arabic number for the interviews: (P1), (P2), (P3) ... (P20).

\section{RESULTS AND DISCUSSION}

Concerning the sociodemographic profile of the participants, it was in the age group between 18 and 37 years old, predominantly women of stable union, with family income of up to 1 minimum wage and complete secondary education.

The software recognized the formation of 188 UCEs (text segments). The number of different forms or different words was 1,142 , with a number of occurrences of 6,708 and a total use of the corpus of $86.17 \%$. The DHC allowed the identification and analysis of the textual domains, as well as the interpretation of the feelings experienced by the mothers of infants with microcephaly, naming them in their respective senses in six classes originating from three axes.

During division, the first axis formed the class 1 , which was related to the feelings before the diagnosis of microcephaly. This axis gave origin to two branches (sub-divisions), represented by classes 5 and 6 , which dealt with the feelings related to the reaction of the mothers to the prejudice of society and their routine with the infants with microcephaly, respectively. Class 2 emerged from a second partition of the corpus, originating the second axis with content portraying the feelings related to limitations and the pursuit of care for infants with microcephaly. The third partition (axis) encompassed classes 3 and 4, related to the acceptance of microcephaly diagnosis and the importance of family support and feelings in coping with the disease, respectively (Figure 1).

\section{Class 1: Feelings before the diagnosis of microcephaly}

When analyzing the mothers' speeches, that was found that they manifested different feelings regarding the diagnosis of microcephaly, some reported having suffered a severe impact referring to intense suffering and reported not believing that a case of microcephaly could be happening in their lives. There were also feelings of impartiality in the face of the problem.

When I heard that my son had microcephaly, it was a shock, because I'd heard about television [...] (P3).
CARVALHO, C. M. S. et al.

[...]So he was born with eight months, but the size of a seven months old, very small, when he was born it was that they measured the head, gave it twenty-nine centimeters, then my feeling was despair, it was my first child [...] (P17).

When I went to make the plan, the pediatrician already sent me to the neurologist, when I arrived at the neurologist he asked for a CT scan, but that he had microcephalus, so my floor disappeared [...] (P15).

My reaction was to cry, I was not expecting that and after that it was just suffering (P7).

The birth of a child with a disability triggers deep suffering in the parents, but can be minimized through family support and the support needed to cope with problems arising from the acquired condition. The moment of giving the news requires a professional attitude of acceptance, with the purpose of strengthening the therapeutic relationship and developing bond and trust between the professional and the family. Further adaptation is related to the ability to find real support, confidence and clarification (FALKENBACH, DREXSLER, WERLER, 2008).

A study developed by Silva (2015) revealed that, generally, feelings experienced by mothers when they first see their child 'can vary from positive feelings and lived with great intensity, to negative feelings such as disappointment and denial.

\section{Class 4: Feelings in coping with microcephaly}

Through the discourse of mothers, different forms and feelings are perceived in the face of microcephaly. For some participants, the birth of a child with microcephaly is related to divine providence and requires resilience in coping with the problem. This is a protective factor for the mother who finds support and comfort in religious beliefs, strengthening the feeling of acceptance and trust.

I was sad at first, but then I clung to God, I knew that if he had sent her that way it was because He knew I would take care of her, I thought that (P6).

[...]I saw if God gave me this way because I had the ability to care for her since she and everything had to multiply love and affection [...] (P20). 


\begin{tabular}{|c|c|c|c|c|c|c|c|c|c|c|c|}
\hline \multirow{2}{*}{\multicolumn{2}{|c|}{$\begin{array}{c}\text { Class 1 } \\
\text { 30 UCE } \\
18.52 \% \\
\text { Feelings before the } \\
\text { diagnosis of microcephaly }\end{array}$}} & \multirow{2}{*}{\multicolumn{2}{|c|}{\begin{tabular}{|c|} 
Class 4 \\
22 UCE \\
$13.58 \%$ \\
Feelings in coping \\
with microcephaly
\end{tabular}}} & \multirow{2}{*}{\multicolumn{2}{|c|}{$\begin{array}{c}\text { Class } 3 \\
29 \text { UCE } \\
17.9 \% \\
\text { Acceptance of the } \\
\text { diagnosis of } \\
\text { microcephaly and } \\
\text { the importance of } \\
\text { family support } \\
\end{array}$}} & \multirow{2}{*}{\multicolumn{2}{|c|}{\begin{tabular}{|c|} 
Class 2 \\
28 UCE \\
$17.28 \%$ \\
Feelings related to \\
the limitations and \\
the search of care \\
for infants with \\
microcephaly \\
\end{tabular}}} & \multirow{2}{*}{\multicolumn{2}{|c|}{$\begin{array}{c}\text { Class } 6 \\
28 \mathrm{UCE} \\
17.28 \% \\
\text { Feelings related to the } \\
\text { routine of mothers of } \\
\text { infants with } \\
\text { microcephaly }\end{array}$}} & \multirow{2}{*}{\multicolumn{2}{|c|}{$\begin{array}{c}\text { Class } 5 \\
25 \text { UCE } \\
15.43 \% \\
\text { Feeling related to the } \\
\text { mother's reaction to } \\
\text { the prejudice of } \\
\text { society }\end{array}$}} \\
\hline & & & & & & & & & & & \\
\hline Words & $\chi^{2}$ & Words & $\chi^{2}$ & Words & $\chi^{2}$ & Words & $\chi^{2}$ & Words & $\chi^{2}$ & Words & $\chi^{2}$ \\
\hline Ultrasonography & 37.03 & Think & 20.86 & Father & 33.55 & Child & 25.37 & Look & 25.16 & Home & 61.22 \\
\hline Microcephaly & 31.5 & God & 16.2 & Crisis & 22.89 & Get & 24.69 & Beginning & 22.47 & To arrive & 27.21 \\
\hline TV & 27.42 & Larger & 14.96 & To receive & 18.15 & Baby & 23.96 & Want & 18.2 & Hour & 25.37 \\
\hline Begin & 22.7 & World & 14.96 & Difficult & 18.15 & Problem & 22.7 & Preconception & 16.75 & Come back & 24.69 \\
\hline Little & 22.18 & Sad & 13.18 & Much & 16.72 & Special & 19.63 & On here & 16.22 & Physiotherapy & 14.19 \\
\hline Tomography & 18.05 & Best & 13.18 & Good & 16.06 & Thing & 12.47 & Teresina & 12.53 & Girl & 10.63 \\
\hline Baby & 18.05 & Need & 12.05 & Help & 15.42 & Son & 10.45 & Get out & 11.87 & Get in & 10.63 \\
\hline Gestation & 18.05 & Right & 11.83 & More & 12.46 & Sit & 9.56 & Calm & 11.15 & Answer & 9.56 \\
\hline Size & 18.05 & Also & 11.83 & Tell & 10.08 & To & 9.56 & Medium & 7.85 & Day & 7.01 \\
\hline Suspicious & 18.05 & Over there & 9.51 & Family & 9.19 & $\begin{array}{l}\text { To } \\
\text { imagine }\end{array}$ & 8.13 & To know & 7.59 & Week & 6.58 \\
\hline Doctor & 17.35 & Behind & 9.47 & Husband & 7.67 & Take & 8.13 & Different & 6.15 & Way & 6.55 \\
\hline Month & 16.6 & Great & 7.34 & Yes & 6.22 & Like this & 7.24 & Come over & 5.74 & Wait & 6.3 \\
\hline Childbirth & 13.45 & Incubator & 7.34 & Enough & 6.22 & People & 6.83 & To ask & 4.93 & Mother & 5.97 \\
\hline Hydrocephalus & 13.45 & Love & 7.34 & Diagnose & 6.22 & Floor & 5.21 & Normal & 4.3 & Morning & 5.21 \\
\hline
\end{tabular}




\begin{tabular}{|l|l|}
\hline Born & 10.6 \\
\hline Be & 9.94 \\
\hline So & 8.46 \\
\hline To give & 8.04 \\
\hline To discover & 7.0 \\
\hline Surgery & 5.88 \\
\hline Case & 5.88 \\
\hline When & 5.0 \\
\hline
\end{tabular}

\begin{tabular}{|l|l|}
\hline After & 6.4 \\
\hline More & 5.84 \\
\hline Fear & 5.5 \\
\hline Husband & 5.34 \\
\hline Concern & 4.64 \\
\hline Development & 4.64 \\
\hline Faith & 4.64 \\
\hline Run & 4.64 \\
\hline
\end{tabular}

\begin{tabular}{|l|l|}
\hline When & 5.8 \\
\hline Mother & 5.49 \\
\hline Follow-up & 4.95 \\
\hline To take & 4.95 \\
\hline Night & 4.95 \\
\hline Explain & 4.95 \\
\hline Cry & 4.64 \\
\hline Accept & 4.57 \\
\hline Develop & 4.37 \\
\hline
\end{tabular}

\begin{tabular}{|l|l|}
\hline Play & 5.21 \\
\hline To force & 5.21 \\
\hline Born & 5.01 \\
\hline Feeling & 4.66 \\
\hline Disease & 4.66 \\
\hline
\end{tabular}

\begin{tabular}{|l|r|}
\hline Live & 4.66 \\
\hline Query & 4.660 \\
\hline Turn & 4.311 \\
\hline \multicolumn{2}{|c}{2} \\
& 3 \\
& 4 \\
& 5 \\
& 6 \\
& 7 \\
& 8
\end{tabular}

9 Figure 1: Thematic Dendrogram of DHC classes. 
Other testimonies pointed to feelings of denial of microcephaly, followed by acceptance based on the belief that they are not the only ones experiencing the same problem and that they can dedicate care to ensure a better quality of life for the newborn child, as described below:

It's very sad, but then I settled, because it's not just people who are going through this, there are a lot of cases even worse I'm already conforming it's helpful [...] (P3).

Silva(2015), portrays the common way in building an ideal centered on the birth of a physically and mentally healthy child. Thus developing images, dreams and hopes around the "being" one imagines, at a time when, in contradiction, the ghost of the malformation haunts throughout the gestational period. The timing of the diagnosis of this type of anomaly causes them great surprise. The experience of knowing that the child has a serious illness generates suffering, doubts and the immediate search for meaning in an attempt to make sense of this situation, since this experience can often be confusing and exhausting, both for the lives of parents, as well as that of their family.

[...]This is a very worrisome issue for me, I just think it's best for him whatever's good for him I want to do, so I can not feel guilty [...] (P11).

[...]But he had another time that I was scared because he has a difficulty swallowing and sometimes he chokes, since almost he does not come back anymore I'm already dealing and learning right [...] (P16)

After the news of the malformation, there is a frustration in the mother's expectations, and it is necessary to adapt the idealized child to the children who is now part of his life, to adapt to his limitations and needs. Many women declare themselves to be winners and stand out for their pride in having overcome so many difficulties related to the care of these children (SILVA, 2012).

\section{Class 3: Acceptance of the diagnosis of microcephaly and the importance of family support.}

From the reading of the interviews of the mothers, it was possible to understand the importance of family and professional support, to overcome the first feelings raised by the news that from that moment this woman will be the mother of a child with microcephaly.
[...]Sometimes we spend the night awake when she does not want to sleep, but no problem, I already learned and I got used to it. [...] (P5).

[...],But thanks to God I'm seeing each passing day he is developing well. I cried a lot when I found out, I cried too much who gave me more comfort was my husband, he always said I had to be strong (P11).

The family of children with some anomaly knows that the development of this child will be slower than other children, but they believe that they will develop within their means. Family and professional support and protection provide security and strength to give continuity to care, especially for the mother, who is most often the primary caregiver. The way the family is supported at the time of diagnosis of a chronic disease directly interferes with the coping of the disease (BOLLA et al, 2013).

I cried, I just cried, I was afraid of everything: not knowing how to take care of the things that she was going to get through. When she was younger, she cried and I cried together, did not know what to do, spent the night awake and she crying (P04).

\section{Class 2: Feelings related to the limitations and the search of care for infants with microcephaly.}

In the interviews, mothers of infants with microcephaly reveal feelings of insecurity and concern about the limitations of the child with microcephaly. Lack of knowledge about the development of the child with microcephaly contributes to accentuate the negative feelings of concern and insecurity, increasing the burden of stress between parents and relatives. However, despite such feelings, mothers seek to have their children develop well and in the future be able to perform tasks like any other child.

[...]For me he is a normal child with his limitations, he is like any other child. Thank God I'm not ashamed! I do stay at home, I go to the mall I go everywhere with him [...] (P15).

[...]I discovered a month before she was born [...]. It's that thing, the feeling of not knowing how to take care, what's it going to be like? So it has several degrees, does not it? She was taken care of by the psychologist and I asked her how she is going to be: if she goes, I can sit, walk and talk (P1). 
For parents of a child with anomaly there is concern about the survival and future of the child, there is ignorance about how to care; Things that can lead to feelings of guilt, impotence. This can cause angst, anxiety and stress to the main caregivers, with the mothers being the main caregiver, not always focused on the original maternal representations, those about the imagined and desired child (LOPES et al, 2011; BRASIL, 2016)

Yes certainly a greater difficulty because he is special, so I get more so because he who picks up things and he can not, so I get sad. (P18).

[...] since holding the neck, since smile, for some a simple smile and little things, more for people who have a child with microcephaly and a lot, a very large conquest [...] (P20).

In the cases of children with some anomaly, support actions, such as the insertion of the child in Early Stimulation Programs, are of great importance. This assistance is fundamental to the family, reduces the anxiety and stress of caregivers, especially the mother, being supported and trained to deal with their child, thus improving the care provided (PEREIRA et al., 2014).

\section{Class 6: Feelings related to the routine of mothers of infants with microcephaly}

There were doubts, difficulties, fears and other issues of daily life, in which they resemble care. Mothers in general are the main caretakers, often feeling overwhelmed, this obligation to take care of some of them because they do not trust and think that no one will know how to take care of their child.

They are the mothers who take them in the doctor's offices, the accompaniments to the treatment centers, and take care of your special child. Some still have other children who need attention. It is they who experience the most diverse types of feelings during every journey. After news of the diagnosis of microcephaly, they state that their lives have changed completely after the birth of the child.

When we have consultation we come home, we are dead tired, I end up crying, not crying with my daughter's anger is that tired cry of wanting to rest, then come those thoughts will be that I do not like my daughter [...] (P13).
She has a month, I take good care of her and the house, at the time she sleeps I take care of things from home [...] (P12).

The arrival of a child brings changes in the life of the mother and her family and the need arises to adapt to the arrival of the baby. When they are born with some health problem, in some moments this can generate frustration in the parents, who idealized a child and was born a different one; in addition, there is a feeling of guilt and excessive behaviors of zeal and care, especially of the mother, in an attempt to repair such feeling (BRASIL, 2015a).

We have physiotherapy once a week and a speech therapist every two weeks. I've already gotten depressed, because we stay, in my case, not even in a city I live, it's in the country and every time I go to the city I pay one hundred reais for tickets [...] (P7).

With the arrival of a special child in the family, there are changes in the family routine, especially the mother, since she is the one who, most of the time, takes care of activities such as taking the child to the consultations and rehabilitation centers. Added to this, there is an impact on the financial issue, as there is an increase in expenses and often the mother needs to devote all of her time to the rehabilitation of the child, failing to contribute to the family income (GONDIM, 2009).

\section{Class 5: Feeling related to the mother's reaction to the prejudice of society}

With the testimony of the mothers interviewed, it was possible to notice a discomfort in the way people look or ask something about the baby, they say they do not have leisure moments due to the time spent with the child with microcephaly. This makes it difficult to accept the idea of having a child with microcephaly. There were other glances where they claim that their life has not changed, that the child does not stop doing nothing.

[...] we know the reality, she does not have eyes and will not see, but sometimes some comments hurt and not good. We know this reality, but I do not like it because there are people asking a lot and it is not good there are people who make unnecessary comments (P1). 
When a child is born, it is faced with a full range of conceptions, having some disability runs the risk of facing prejudice and complicated situations of dealing, with this the parents end up developing a concern with what other people can talk about their children (FALKENBACH, DREXSLER, WERLER, 2008).

I went into shock, I cried I did not believe it, I got to say I did not want a child like that, I know I cried, cried a lot said nothing, just cried (P2).

But I know this will end one day, because we do not have leisure moments (P13).

To Sá (2013), there is a process of transformation in the family life with the arrival of a baby, the emotional and organizational life in the mute family, bringing new learning, especially with the arrival of a child with microcephaly.

Given the peculiarities of this theme, microcephaly has been studied, mainly, in its pathophysiological aspects, with contributions to the clinical practice. However, it is relevant to invest in qualitative studies that involve other domains of care, such as the meanings of the disease by the different actors involved, such as other family members and professionals involved in care, especially nurses in primary health care. Knowledge of these meanings may be useful for future scientific discussions about the importance of training for management of self-care in chronic conditions and educational practice in health.

It is pointed out as limitation of this study the participation of only mothers of infants. In this way, perhaps, the feelings described in this study are not the same as for mothers of children in another phase of the life cycle. However, this research contributes to the advancement of knowledge, and thus contributes to humanized care, through the eyes of health professionals, especially nurses, for mothers of infants with microcephaly.

\section{CONCLUSION}

It has been shown that for mothers, the birth of a child with microcephaly is a delicate and conflicting moment in their lives, because it is a new and unexpected event in their life, too, because it is the loss of the idealized baby. Thus the main feelings evidenced pointed from uncertainties, doubts, fear, losses, impotence, insecurity and sadness to the feeling of accomplishment.

RESUMO: Microcefalia é uma malformação congênita na qual o cérebro não se desenvolve adequadamente. Pode ser o resultado de uma série de fatores, desde a desnutrição da mãe, abuso de drogas, infecções durante a gravidez, dentre outros. No contexto familiar, o nascimento de uma criança com microcefalia pode produzir profundas mudanças e necessidades nas dimensões psicossocial e financeira da família. Com base neste contexto, o objetivo do estudo foi desvelar os sentimentos vivenciados por mães de lactentes com microcefalia. Para tanto, foi desenvolvido um estudo descritivo, exploratório, com abordagem qualitativa, realizado em uma maternidade de referência, localizada em uma grande cidade do Nordeste do Brasil, com 20 (vinte) mães. Para processar os dados coletados, foi utilizado o software IRaMuTeQ e os resultados foram analisados por meio da Classificação Hierárquica Descendente. Os resultados foram apresentados por meio de um dendograma em seis classes temáticas: Sentimentos de mães antes do diagnóstico de microcefalia; Sentimentos de mães no enfrentamento da microcefalia; Aceitação do diagnóstico de microcefalia e a importância do apoio familiar; Sentimentos de mães relacionados às limitações e a busca de cuidados para lactentes com microcefalia; Sentimentos de mães relacionados à rotina de mães de lactentes com microcefalia e Sensação relacionada à reação da mãe ao preconceito da sociedade. Concluiu-se que o nascimento de uma criança com microcefalia é considerado um momento delicado e conflituoso para a vida das mães, por ser um evento novo e inesperado em suas vidas; além ocorrer a perda do bebê idealizado a ser substituído por um bebê que precisará de cuidados especializados.

PALAVRAS-CHAVE: Microcefalia. Sentimentos. Anormalidades Congênitas. Cuidados de Enfermagem.

\section{REFERENCES}

BOLLA, B. A.; et al. Cuidado da criança com anomalia congênita: a experiência da família. Esc. Anna Nery Rev. Enferm, v. 17, n. 2, p. 284-290, 2013. https://doi.org/10.1590/S1414-81452013000200012 
BRASIL. Ministério da Saúde. Protocolo de Vigilância e Resposta à Ocorrência de Microcefalia Relacionada à Infecção pelo Vírus Zika -Plano Nacional de Enfretamento à Microcefalia. Brasília, Ministério da Saúde: 2015a.

BRASIL. Ministério da Saúde. Protocolo de Atenção à Saúde e Resposta à Ocorrência de Microcefalia Relacionada à Infecção pelo Vírus Zika, Ministério da Saúde, 2015b.

BRASIL. Ministério da Saúde. Secretaria de Atenção à Saúde. Diretrizes de estimulação precoce: crianças de zero a 3 anos com atraso no desenvolvimento neuropsicomotor decorrente de microcefalia. Ministério da Saúde, Secretaria de Atenção à Saúde. Brasília: Ministério da Saúde, 2016.

FALKENBACH, A. P.; DREXSLER, G.; WERLER, V. A relação mãe/criança com deficiência: sentimentos e experiências. Ciênc Saúde Coletiva, v. 13, n. 2, p. 2065-73, 2008. https://doi.org/10.1590/S141381232008000900011

GONDIM, K. M. Sentimentos de mães de crianças com paralisia cerebral. Estudo iluminado na teoria da incerteza na doença. 2009. p.146. Dissertação (Mestrado) Universidade Federal do Ceará. 2009.

JESUS, G. J.; et al. Difficulties of living with HIV/Aids: Obstacles to quality of life. Acta paul. enferm, v. 30, n. 3, p. 301-307, 2017. https://doi.org/10.1590/1982-0194201700046

LOPES, F. N. et al. A vivência materna diante do defeito congênito: contribuições para a prática da enfermagem. HU Revista, v. 37, n. 1, p. 47-54, 2011.

MINAYO, M. C. S. (org.). Pesquisa social: teoria, método e criatividade. 29. ed. Petrópolis, RJ: Vozes, 2010.

MINAYO, M. C. S. Amostragem e saturação em pesquisa qualitativa: consensos e controvérsias. Revista Pesquisa Qualitativa, v. 5, n. 7, p. 1-12, 2017.

PEREIRA, V. A.; et al. Desenvolvimento do bebê nos dois primeiros meses de vida: variáveis maternas e sociodemográficas. Pensando Famílias, v. 18, n. 1, p. 63-77, 2014.

RATINAUD, P.; MARCHAND, P. Application of the ALCESTE method to the large corpus and stabilised lexical worlds or 'cablegate', using IRAMUTEQ. Actes des 11eme JADT. P. 835-44, 2012. Available from: http://lexicometrica.univ-paris3.fr/jadt/ jadt2012/Communications/Ratinaud,\%20Pierre\%20et\%20al.\%20-\%20 Application\%20de\%20la\%20methode\%20Alceste.pdf

REIS, R. P. Aumento dos casos de microcefalia no Brasil. Rev. méd. Minas Gerais, v. 25, n. S6, p. 88-91 2015.

RIBEIRO, I. G. et al. Microcefalia no Piauí, Brasil: estudo descritivo durante a epidemia do vírus Zika, 20152016. Epidemiol. Serv. Saude, v. 27, n. 1, p. 1-11, 2018.

RODRIGUES, P. S.; et al . Occupational accidents among nursing professionals working in critical units of an emergency service. Esc. Anna Nery, v. 21, n. 2, e20170040, 2017.

SÁ, L. M. S. M. et al. Intervenção precoce e microcefalia: estratégias de intervenção eficazes. 2013. 182p. Dissertação (Mestrado). Escola Superior de Educação João de Deus. Lisboa, 2013.

SILVA, E. J. A.; MARANHÃO, D. G. Cuidados de enfermagem às crianças com necessidades especiais de saúde. Rev Enferm UNISA. v. 13, n. 2, p. 117-20, 2012.

SILVA, P. L. N.; et al. Percepção materna sobre neonato com malformação congênita: estudo descritivo. Onlline Brazilian Journal of Nursing, v. 17, n. 3, p.190-196, 2015 
SILVA, S. M. S.; VASCONCELOS, E. M. R.; ARAÚJO, E. D. Mulheres, mães e vírus zika: um olhar para os anseios materno. Rev enferm UFPE on line, v.11(esp), 2017.

SOUSA, A. F. L.; et al . Social representations of biosecurity in nursing: occupational health and preventive care. Rev. Bras. Enferm, v. 69, n. 5, p. 864-871, Oct. 2016. https://doi.org/10.1590/0034-7167-2015-0114

SOUSA, A. F. L.; et al . Social representations of community-acquired infection by primary care professionals. Acta paul enferm, v. 28, n. 5, p. 454-459, Aug. 2015. https://doi.org/10.1590/1982-0194201500076 